\title{
ESTIMATION OF NUMBER, MEAN SIZE AND SIZE DISTRIBUTION OF HUMAN SPERMATOZOA IN OLIGOSPERMIA USING A COULTER COUNTER
}

\author{
JANET BROTHERTON* AND G. BARNARD $\uparrow$ \\ Schering Chemicals Ltd, Burgess Hill, Sussex
}

(Received 8th October 1973)

Summary. A Coulter counter, Model $Z_{B}$ Industrial, was calibrated for the size distribution of cells. A method was then developed for the counting and sizing of human spermatozoa after the removal of contaminating matter with Zaponin. For twenty-five men with normospermia ( $>40 \times 10^{6}$ spermatozoa $/ \mathrm{ml}$ semen) the mean sperm size was a volume of $25.6 \mu \mathrm{m}^{3}$ or a diameter of $3.65 \mu \mathrm{m}$, both in terms of an equivalent sphere. The size distribution was positively skewed with a mode at a volume of $19.4 \mu \mathrm{m}^{3}$ or a diameter of $3.33 \mu \mathrm{m}$. A number of these specimens showed gross structural abnormalities on microscopic examination and it was very difficult to define a normal semen specimen. There were three men with Grade I oligospermia ( $>30 \times 10^{6}$ spermatozoa $\left./ \mathrm{ml}\right)$ and twenty-five men with Grade II oligospermia ( $>20 \times 10^{6}$ spermato$\mathrm{zoa} / \mathrm{ml}$ ). Of the latter, eighteen showed a peak (mode) in the size distribution similar to that found in the cases of normospermia and Grade I oligospermia, except that the peak was less sharp and often shifted significantly from the normal range of values. Samples from the remaining seven showed no peak. Below $12 \times 10^{6}$ spermatozoa $/ \mathrm{ml}$ which was taken as the dividing line for Grade III oligospermia, none of the curves showed a peak. The smooth curves indicated a greater degree of abnormality, as was shown by microscopical examination. As the sperm count in the series gradually decreased, the proportion of abnormal forms gradually increased. The various abnormalities could not be identified in terms of the known developmental stages in normal spermatogenesis. There were nine cases of azoospermia, but the Coulter counter was not useful for specimens of $<5 \times 10^{6}$ spermatozoa $/ \mathrm{ml}$. When an adjustment was made to cut out particles above a volume of $35 \mu \mathrm{m}^{3}$ and below a volume of $14 \mu \mathrm{m}^{3}$, the Coulter and haemocytometer counts showed an almost exact correlation. These results are discussed in relation to the possible benefits of weak androgen therapy for oligospermia and the possible genetic abnormalities involved.

\footnotetext{
* Present address: Department of Chemotherapy, Schering A.G., 1 Berlin 65, Postfach 650311 , Germany.

$\dagger$ Present address: Department of Obstetrics and Gynaecology, King's College Hospital Medical School, Denmark Hill, London.
} 


\section{INTRODUCTION}

The microscopic examination of a semen specimen is one of the earliest and most important operations carried out in the investigation of male subfertility. Elaborate protocols have been devised so that this examination can yield the maximum amount of information (MacLeod, 1965; Eliasson, 1971 ; Joël, 1971; Schirren, 1972). The number of spermatozoa is estimated using a haemocytometer and the count includes the abnormal and juvenile forms. A separate estimate is then made of the proportion of these forms. There is no substitute for a microscopic examination but attempts have been made previously to substitute a non-manual method of determining the sperm count. A Coulter counter has been used successfully for the spermatozoa of rabbits (Fowler \& Hellman, 1965; Kilhström \& Fjellström, 1967; Stranzinger \& Paufler, 1969), guinea-pigs (Laurence \& Carpuk, 1963) and bulls (Glover \& Phipps, 1962; Iversen, 1964; Stranzinger \& Paufler, 1968). Although methods have been reported for human spermatozoa (Segal \& Laurence, 1962; Gordon, Moore, Thorslund \& Paulsen, 1965), these have not come into general use.

This study was undertaken in order to try to develop an automatic method for assessing the quality of the human ejaculate, both with respect to the sperm count and to the types of spermatozoa present.

\section{Patients}

\section{MATERIALS AND METHODS}

All semen specimens were obtained from a subfertility clinic. The first sixteen specimens were selected as being 'normal' in count and were used for preliminary studies on the feasibility of the techniques. The next eighty specimens were examined consecutively over a period of 3 months on an unselected basis. Most of the patients involved were known to be oligospermic but a few were expected to be normal. Four patients were seen twice, thus there were only seventy-six clinical cases. Valid counts were obtained for seventy-two of the eighty semen specimens and the size distributions were obtained and analysed in sixty-eight of these.

\section{Calibration of the Coulter counter}

Calibration of the Coulter counter, Model $Z_{B}$ Industrial, was carried out in the same manner and with mostly the same standard particles as those already described for the Model F (Brotherton, 1969a), Model B Medical (Brotherton, 1969b) and Model A (Brotherton, 1971). The Model $Z_{B}$ is very similar to the Model $B$ in design. Industrial types have an additional matching switch, $M$, which enables investigations to be carried out at osmolarities different from those of body fluids.

The calculation of the machine constant $(\mathrm{K})$ was similar to that for the Model B Medical but incorporated a factor for the matching switch. The machine constant was determined graphically for nineteen different 'standard' particles of pollen and latex (Brotherton, 1969a, b) for a $70 \mu \mathrm{m}$ diameter aperture.

\section{Semen examination}

Semen specimens were examined microscopically immediately after lique- 
faction. A haemocytometer count was made after a dilution of 1 in 10. Abnormal and juvenile forms, including 'cells' (cellular débris), were included in the total count and their proportion was also estimated. The degree of motility and the $\mathrm{pH}$ was noted. A smear was stained by the Papanicolaou method using an automatic staining machine. Phase-contrast photomicrographs of living specimens were taken the next day and any residual motility was noted.

The number of spermatozoa and their size distribution were measured as soon as possible after liquefaction using the Coulter counter with the aperture of stated diameter $70 \mu \mathrm{m}$, nominal aperture diameter of $70.7 \mu \mathrm{m}$ and actual aperture diameter of $69.9 \mu \mathrm{m}$. As the differences between the actual and nominal values were so small, the nominal values were used throughout without any significant loss of accuracy.

Table 1. Machine settings used with the Model $Z_{B}$ Coulter counter

\begin{tabular}{|c|c|c|c|c|}
\hline & & \multicolumn{3}{|c|}{ Combination } \\
\hline & & $I$ & $I I$ & $I I I$ \\
\hline $\begin{array}{l}\text { Machine } \\
\text { settings }\end{array}$ & $\begin{array}{l}\mathrm{G} \\
\mathrm{M} \\
\mathrm{I} \\
\mathrm{A} \\
\mathrm{IB} / \mathrm{M}\end{array}$ & $\begin{array}{l}0 \\
2 \\
\frac{1}{4} \\
\frac{1}{8} \\
0 \cdot 01563\end{array}$ & $\begin{array}{l}0 \\
2 \\
0.354 \\
\frac{1}{8} \\
0.02213\end{array}$ & $\begin{array}{l}0 \\
2 \\
\frac{1}{2} \\
\frac{1}{8} \\
0 \cdot 03125\end{array}$ \\
\hline $\begin{array}{l}\text { Range of } \\
\text { sizes } \\
\text { covered } \\
\text { when } \\
\begin{aligned} \mathrm{D} & =\mathrm{D}_{\mathrm{N}} \\
& =70.7 \mu \mathrm{m}\end{aligned}\end{array}$ & $\begin{array}{l}\mathrm{T}=12 \cdot 5 \\
\mathrm{~T}=100 \\
\mathrm{~T}=10 \\
\mathrm{~T}=12 \cdot 5 \\
\mathrm{~T}=100 \\
\mathbf{F}\end{array}$ & $\begin{array}{l}\mathrm{d}=2.037 \mu \mathrm{m} \\
\mathrm{d}=4.074 \mu \mathrm{m} \\
\mathrm{V}=3.54 \mu \mathrm{m}^{3} \\
\mathrm{~V}=4.425 \mu \mathrm{m}^{3} \\
\mathrm{~V}=35.4 \mu \mathrm{m}^{3} \\
0.354 \mu \mathrm{m}^{3}\end{array}$ & $\begin{array}{l}\mathrm{d}=2.296 \mu \mathrm{m} \\
\mathrm{d}=4.571 \mu \mathrm{m} \\
\mathrm{V}=5 \mu \mathrm{m}^{3} \\
\mathrm{~V}=6.25 \mu \mathrm{m}^{3} \\
\mathrm{~V}=50 \mu \mathrm{m}^{3} \\
0.5 \mu \mathrm{m}^{3}\end{array}$ & $\begin{array}{l}\mathrm{d}=2.568 \mu \mathrm{m} \\
\mathrm{d}=5.135 \mu \mathrm{m} \\
\mathrm{V}=7.07 \mu \mathrm{m}^{3} \\
\mathrm{~V}=8.85 \mu \mathrm{m}^{3} \\
\mathrm{~V}=70.7 \mu \mathrm{m}^{3} \\
0.707 \mu \mathrm{m}^{3}\end{array}$ \\
\hline \multicolumn{2}{|c|}{$\begin{array}{l}\text { Approximate } \\
\text { plateau } \\
\text { for spermatozoa }\end{array}$} & $\mathrm{T}=38$ & $\mathrm{~T}=28$ & $\mathbf{T}=16$ \\
\hline \multicolumn{2}{|c|}{$\begin{array}{l}\text { Approximate } \\
T_{+} \text {value } \\
\text { for spermatozoa }\end{array}$} & $\mathrm{T}=65$ & $\mathrm{~T}=50$ & $\mathrm{~T}=35$ \\
\hline \multicolumn{2}{|c|}{$\begin{array}{l}\text { Approximate extent of } \\
\text { sperm count }\end{array}$} & $\mathrm{T}=100$ & $\mathrm{~T}=70$ & \\
\hline
\end{tabular}

Four different semen diluents were tried. The first was Isoton (Coulter Electronics Ltd) which is a modification of Eagle's medium. The second was the semen diluent of Gordon et al. (1965) consisting of $1 \%$ Zaponin (Coulter Electronics Ltd) in Isoton:Isoton:glacial acetic acid, 10:85:5 by vol. This was used as the entire semen diluent. The third was Isoton to which two drops of Zaponin per $100 \mathrm{ml}$ diluted semen were added 1 min before the count was made (Brotherton, 1969a). The fourth was a cetrimide-citrate-saline reagent (D'Angelo \& Lacombe, 1962; Brotherton, 1969a) which was also used as the entire semen diluent. The third method was selected for routine purposes.

The machine settings used are shown in Table 1 . These have been designated 'Combinations I, II and III'. The same arbitrary values of I and A machine settings were always used to produce the chosen values of $\mathrm{IB} / \mathrm{M}$. The range of 
cell size in terms of both diameter and volume for the three combinations is shown. The upper threshold dial was turned off and only the lower used. For counting of spermatozoa, duplicate counts in $0.5 \mathrm{ml}$ semen suspension were made at $\mathrm{T}=28$ and $\mathrm{T}=70$ for Combination II and at $\mathrm{T}=38$ and $\mathbf{T}=100$ for Combination $\mathbf{I}$.

All counts were corrected for coincidence using the tables provided with the instrument. For calculation of the total number of spermatozoa per ml semen, the corrected count at the higher $T$ value was subtracted from the corrected count at the lower $\mathrm{T}$ value and the difference was multiplied by the dilution factor and by 2 to correct for only $0.5 \mathrm{ml}$ of the diluted solution being counted. Thus, the total factor was usually $\times 2000$ or $\times 4000$.

For the determination of size distribution, duplicate counts were made at suitable intervals along the lower threshold scale from $T=10$ to $T=100$ and a graph was plotted of count against $T$ values. Values for the count were recorded for every 2 units of $T$. These were corrected for coincidence and subtracted from the previous value. In this way, the difference in count for each interval of 2 units of $T$ was calculated. These values were plotted as a histogram and a smooth curve was drawn through the values. The $\mathrm{T}_{\frac{1}{2}}$ value was calculated in the usual manner.

\section{RESULTS}

\section{Calibration of the Coulter counter}

The machine constant, $\mathrm{K}$, was 21.9 for the $70-\mu \mathrm{m}$ diameter aperture, based on a graph with forty-nine points.

\section{Effects of different diluents}

Simple dilution of semen with Isoton produced the types of curves shown in Text-fig. 1a. Although six possible values of $I B / M$ were tried, none of the curves showed a plateau and it was impossible therefore to select any value of $T$ which would serve as a minimum size level for a sperm count. Similarly, a plateau was not found using the semen diluent of Gordon et al. (1965) containing acetic acid and saponin (the dashed curve in Text-fig. 1b). With this diluent, there was a considerable reduction of background material and of sperm mass, which was too severe for the diluent to be practical in spite of all the dilutions and counts being performed as quickly as possible.

Treatment with Zaponin immediately before counting was found to be much more satisfactory, as shown in Text-fig. 1(b). The semen sample was the same as that remaining untreated in Text-fig. 1. Microscopic examination of a treated specimen showed that background droplets and débris had been removed while the tails of the spermatozoa remained intact and were still attached to the sperm heads.

Table 2 shows the parameters of the particle size distribution curves for semen samples from three men where the effect of the cetrimide-citratesaline reagent was compared with that of the Zaponin reagent. The curves were altered only very slightly and the $T_{\frac{1}{2}}$ values and total counts were hardly affected. The changes that occurred would appear to be within the experi- 
mental error of the method. The mean decrease in mean cell volume was not greater than $1.36 \mu \mathrm{m}^{3}$ for the cetrimide-citrate-saline reagent and was negligible. It was concluded that there was no significant difference between the two reagents.

\section{Type of size distribution}

To illustrate the method of calculating the size distribution, Text-fig. 2 shows the curves produced for Combinations I, II and III for Patient no. 8. All three curves taper at the lower end to a low blank value but only the complete curve produced with Combination III is shown in full, as a smaller curve.

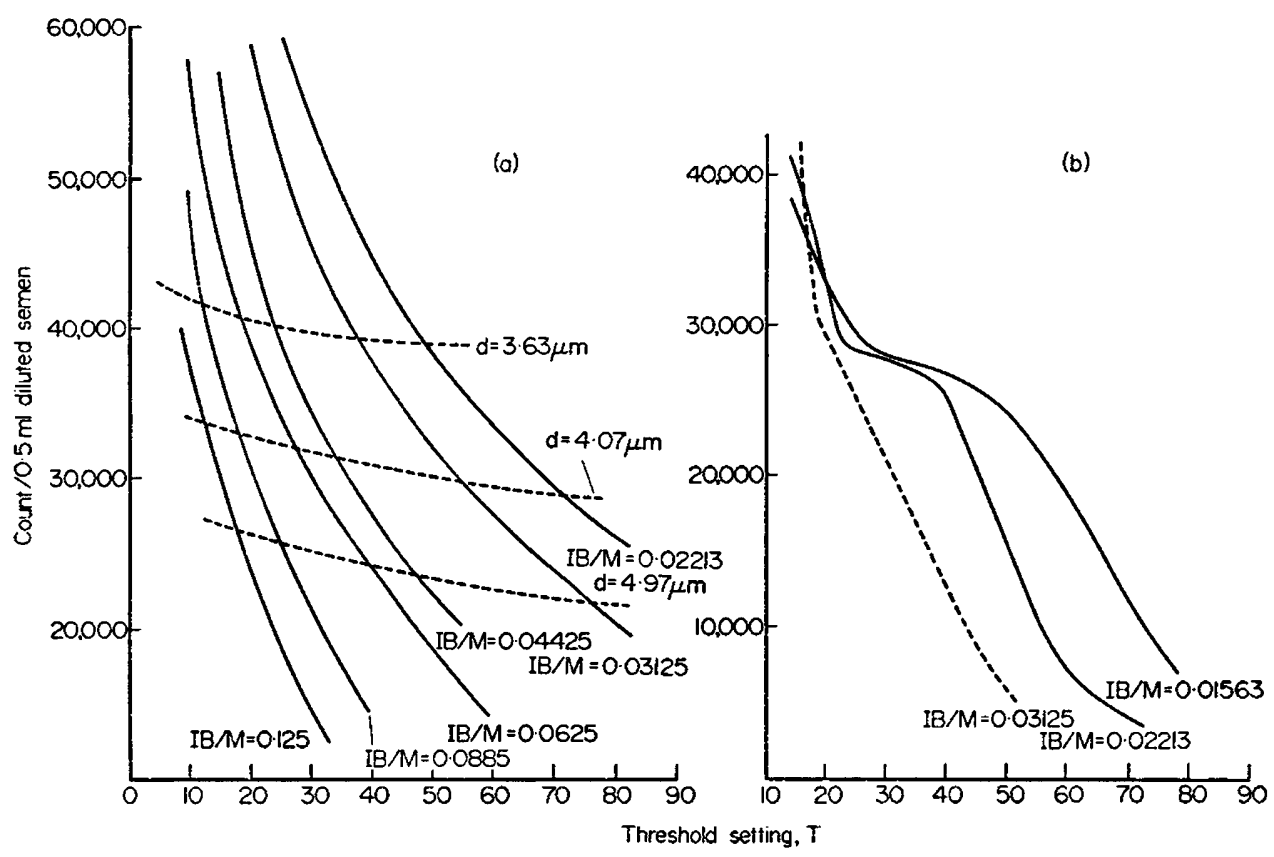

TEXT-FIG. 1. Size distribution curves for human spermatozoa after dilution of semen with (a) Isoton or (b) Zaponin (-) or semen diluent $(-\cdots)$ (see text) at a variety of machine settings on a Coulter counter.

The size distribution of this curve was calculated for equal intervals of volume, equal intervals of diameter and equal intervals of logarithmic volume. The plots of the size distributions are shown in Text-figs $3(\mathrm{a}), 3(\mathrm{~b})$ and $3(\mathrm{c})$, respectively. It is seen that the shape of the curve is positively skewed and that this could not be altered by any of the transformations tested. The combination (III) used to plot this complete curve showing the tail was not generally suitable for routine measurement as the plateau and peak appeared at a position of $T$ too near the lower end of the threshold scale for accuracy. For routine measurements, only Combinations I and II were used and eventually Combination II was selected as being the most useful. All subsequent results were expressed in terms of equal units of spherical volume. 


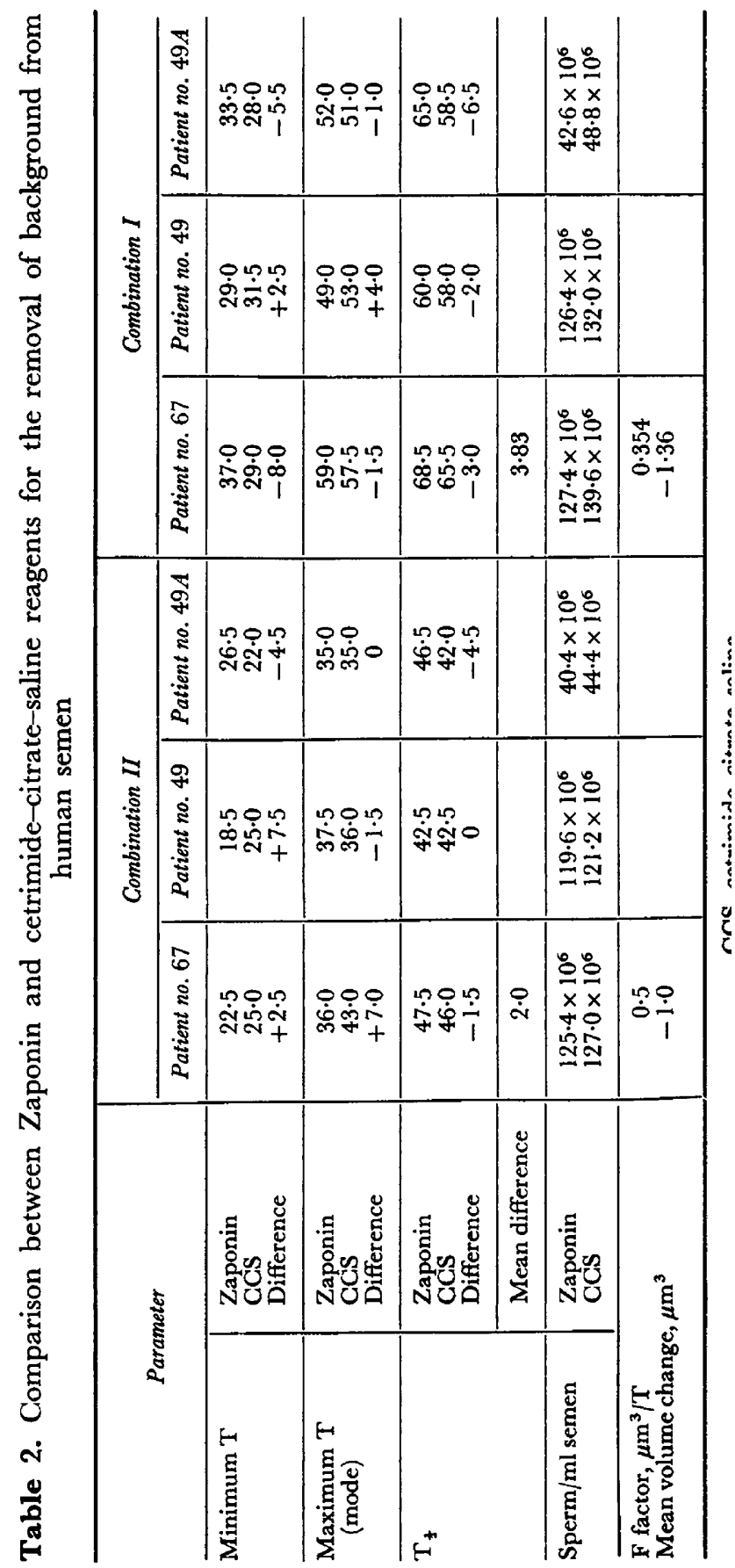


Size distribution of human spermatozoa

Text-figures $4(\mathrm{a}), 4(\mathrm{~b}), 4(\mathrm{c})$ and $4(\mathrm{~d})$ show some of the size distributions obtained for equal units of volume using Combination II as the machine setting. The curves are numbered according to the case number. 'Normal' curves are shown in Text-fig. 4(a). 'Normal' was used as the designation when both the Coulter and haemocytometer counts gave a value greater than $40 \times 10^{6}$ spermatozoa $/ \mathrm{ml}$ semen. The characteristics of all of the twenty-five 'normal' curves

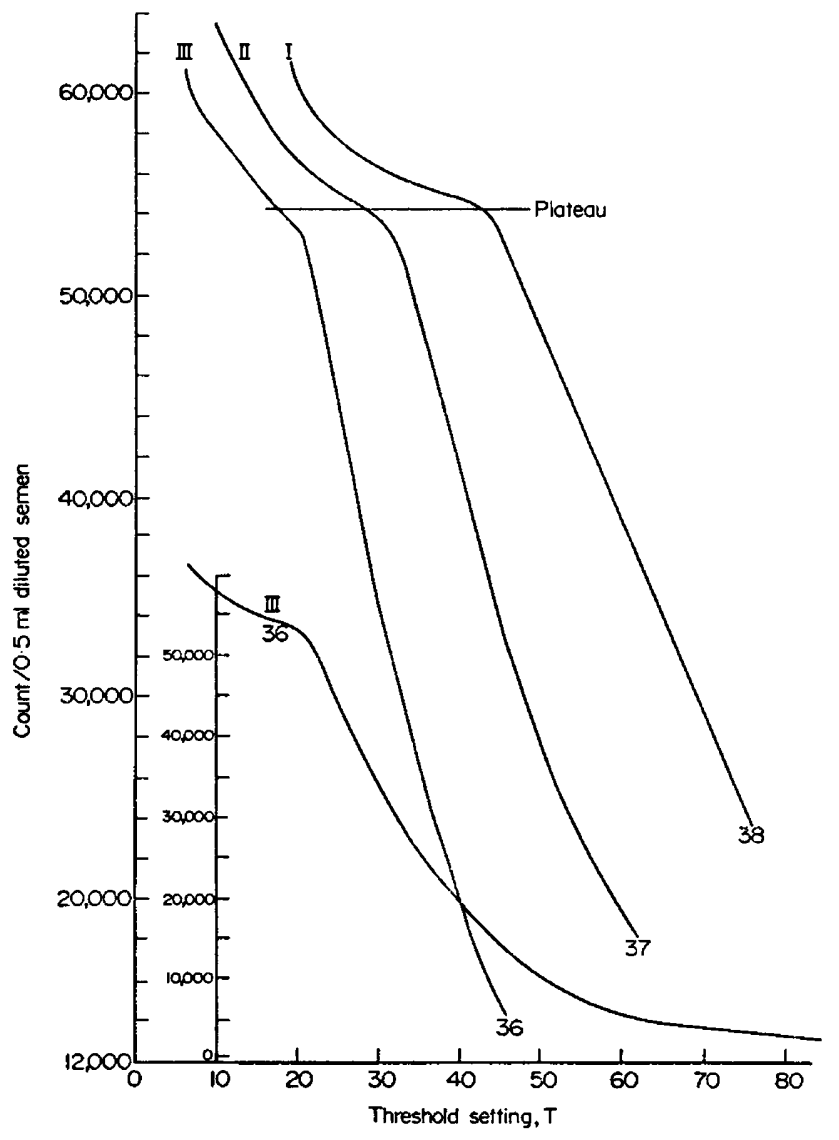

T'ExT-FIG. 2. Typical size distribution curves, of human spermatozoa (Patient no. 8) after treatment of the semen by Zaponin, produced by Combinations I, II and III of the machine settings on a Coulter counter.

have been summarized in Table 3 , together with their haemocytometer counts. The counts obtained with the Coulter counter are shown as 'corrected', when the higher threshold level had been used to cut out large particles, and as 'uncorrected' when this had not been done. The 'uncorrected' counts were slightly higher.

Some of the particle size distributions for thirty-four oligospermic patients $\left(<40 \times 10^{6}\right.$ spermatozoa/ml) are shown in Text-figs $4(\mathrm{~b})$ and $4(\mathrm{c})$. All the curves are summarized in Table 4 . Two types of curves were seen, those with 
Table 3. Summary of counting and size distribution data of particles in normospermic, oligospermic and azoospermic human semen samples

\begin{tabular}{|c|c|c|c|c|c|c|c|}
\hline \multirow{3}{*}{$\begin{array}{c}\text { Sample } \\
\text { no. }\end{array}$} & \multirow{3}{*}{$\begin{array}{l}\text { Total } \\
\text { dilution } \\
\text { factor }\end{array}$} & \multicolumn{3}{|c|}{ Sperm count $\times 10^{6} / \mathrm{ml}$} & \multirow{2}{*}{\multicolumn{3}{|c|}{$\begin{array}{c}\text { T values from the size } \\
\text { distribution } \\
\text { curve }\end{array}$}} \\
\hline & & \multirow[b]{2}{*}{ Manual } & \multicolumn{2}{|c|}{ Coulter } & & & \\
\hline & & & $\underset{\text { rected }}{\text { Cor- }}$ & $\begin{array}{l}\text { Uncor- } \\
\text { rected* }\end{array}$ & Min. & $\begin{array}{l}\text { Modal } \\
\text { Max. }\end{array}$ & $\underset{T_{t}}{\text { Mean }}$ \\
\hline $\begin{array}{c}\text { Normals } \\
32 \\
43 \\
36 \\
67 \\
74 \\
49 \\
37 \\
39 \\
22 \\
13 \\
9 \\
8 \\
10 \\
7 \\
61 \\
40 \\
52 \\
42 \\
57 \\
6 \\
77 \\
50 \\
5 \\
31 \\
49 \mathrm{~A}\end{array}$ & $\begin{array}{r}10000 \\
8000 \\
4000 \\
2000 \\
2000 \\
4000 \\
2000 \\
2000 \\
2000 \\
2000 \\
4000 \\
2000 \\
4000 \\
2000 \\
2000 \\
2000 \\
2000 \\
2000 \\
2000 \\
2000 \\
2000 \\
2000 \\
2000 \\
2000 \\
2000\end{array}$ & $\begin{array}{l}98 \\
83 \\
\\
61 \\
86 \\
63 \\
\\
\\
65\end{array}$ & $\begin{array}{l}476 \\
198 \\
125 \\
114 \\
120 \\
95 \cdot 2 \\
93 \cdot 0 \\
91 \cdot 2 \\
81 \cdot 6\end{array}$ & $\begin{array}{l}566 \\
240 \\
252 \\
150 \\
173 \\
107 \\
114 \\
123 \\
103 \\
156 \\
114 \\
127 \\
100 \\
108 \\
82 \cdot 0 \\
98 \cdot 2 \\
76 \cdot 6 \\
93 \cdot 0 \\
77 \cdot 0 \\
63 \cdot 2 \\
78 \cdot 2 \\
75 \cdot 6 \\
56 \cdot 2\end{array}$ & $\begin{array}{l}24 \cdot 0 \\
24 \cdot 5 \\
30 \cdot 0 \\
23 \cdot 0 \\
\\
27 \cdot 0 \\
25 \cdot 5 \\
27 \cdot 0 \\
25 \cdot 5 \\
23 \cdot 0 \\
24 \cdot 0 \\
22 \cdot 5 \\
25 \cdot 0 \\
28 \cdot 5 \\
26 \cdot 0 \\
31 \cdot 5 \\
29 \cdot 0 \\
28 \cdot 5 \\
27 \cdot 5 \\
23 \cdot 0 \\
35 \cdot 0 \\
28 \cdot 0\end{array}$ & $\begin{array}{l}37 \cdot 5 \\
35 \cdot 5 \\
41 \cdot 0 \\
36 \cdot 0 \\
\\
41 \cdot 0 \\
41 \cdot 0 \\
40 \cdot 0 \\
40 \cdot 0 \\
36 \cdot 5 \\
37 \cdot 5 \\
40 \cdot 0 \\
38 \cdot 0 \\
35 \cdot 0 \\
37 \cdot 0 \\
44 \cdot 0 \\
37 \cdot 5 \\
42 \cdot 5 \\
40 \cdot 0 \\
35 \cdot 5 \\
43 \cdot 0 \\
37 \cdot 5 \\
40 \cdot 0\end{array}$ & $\begin{array}{l}47 \cdot 0 \\
46 \cdot 0 \\
58 \cdot 5 \\
55 \cdot 0 \\
57 \cdot 0 \\
\\
50 \cdot 5 \\
\\
52 \cdot 0 \\
49 \cdot 0 \\
44 \cdot 5 \\
50 \cdot 0 \\
52 \cdot 0 \\
49 \cdot 0 \\
51 \cdot 5 \\
46 \cdot 0 \\
56 \cdot 5 \\
39 \cdot 0 \\
54 \cdot 5 \\
54 \cdot 5 \\
47 \cdot 0 \\
56 \cdot 0 \\
60 \cdot 0 \\
48 \cdot 0\end{array}$ \\
\hline \multicolumn{8}{|c|}{ Oligospermia, Grade I, with peak } \\
\hline $\begin{array}{l}17 \\
41 \\
34\end{array}$ & $\begin{array}{r}1333 \\
1000 \\
+1000\end{array}$ & $\begin{array}{l}39 \\
31 \\
31\end{array}$ & $\begin{array}{l}45 \cdot 5 \\
30 \cdot 6 \\
29 \cdot 7\end{array}$ & $\begin{array}{l}61 \cdot 5 \\
48 \cdot 5 \\
35 \cdot 4\end{array}$ & $\begin{array}{l}44 \cdot 0 \\
31 \cdot 0\end{array}$ & $\begin{array}{c}55 \cdot 0 \\
40 \cdot 0 \\
(25 \cdot 0)\end{array}$ & $\begin{array}{c}51 \cdot 0 \\
58 \cdot 5 \\
(43 \cdot 5)\end{array}$ \\
\hline \multicolumn{8}{|c|}{ Oligospermia, Grade II, with peak } \\
\hline $\begin{array}{l}19 \\
14 \\
25 \\
65 \\
33 \\
46 \\
26 \\
54 \\
72 \\
3 \\
35 \\
60 \\
38 \\
20 \\
18 \\
53 \\
59\end{array}$ & $\begin{array}{r}800 \\
2000 \\
1000 \\
2000 \\
2000 \\
1000 \\
1000 \\
2000 \\
2000 \\
800 \\
2000 \\
2000 \\
1000 \\
1000 \\
667 \\
2000 \\
1000\end{array}$ & $\begin{array}{l}29 \\
15 \\
33 \\
16 \\
44 \\
32 \\
47 \\
29 \\
\\
43 \\
27 \\
31 \\
21 \\
19 \\
16 \\
13\end{array}$ & $\begin{array}{l}28 \cdot 5 \\
13 \cdot 6 \\
26 \cdot 2 \\
25 \cdot 6 \\
25 \cdot 1 \\
24 \cdot 6 \\
22 \cdot 6 \\
22 \cdot 2 \\
19 \cdot 5 \\
18 \cdot 8 \\
17 \cdot 8 \\
16 \cdot 8 \\
16 \cdot 5 \\
15 \cdot 5 \\
15 \cdot 0 \\
14.5\end{array}$ & $\begin{array}{l}42 \cdot 4 \\
37 \cdot 8 \\
28 \cdot 6 \\
55 \cdot 0 \\
34 \cdot 8 \\
38 \cdot 1 \\
36 \cdot 2 \\
28 \cdot 3 \\
30 \cdot 6 \\
23 \cdot 0 \\
38 \cdot 4 \\
22 \cdot 2 \\
29 \cdot 3 \\
28 \cdot 0 \\
23 \cdot 9 \\
31 \cdot 4 \\
19 \cdot 9\end{array}$ & $\begin{array}{l}34 \cdot 0 \\
30 \cdot 0 \\
30 \cdot 0 \\
28 \cdot 5 \\
32 \cdot 0 \\
26 \cdot 5 \\
26 \cdot 5 \\
\\
\\
27 \cdot 0 \\
32 \cdot 0 \\
\\
32 \cdot 5 \\
32 \cdot 0 \\
37 \cdot 0\end{array}$ & $\begin{array}{l}43 \cdot 5 \\
41 \cdot 0 \\
35 \cdot 5 \\
40 \cdot 0 \\
40 \cdot 5 \\
41 \cdot 5\end{array}$ & $\begin{array}{l}55 \cdot 0 \\
44 \cdot 0 \\
74 \cdot 0 \\
73 \cdot 5 \\
54 \cdot 0 \\
56 \cdot 0 \\
53 \cdot 5 \\
50 \cdot 5 \\
50 \cdot 5 \\
51 \cdot 5 \\
49 \cdot 0 \\
49 \cdot 0 \\
62 \cdot 0 \\
61 \cdot 0 \\
55 \cdot 0 \\
72.5 \\
51.5\end{array}$ \\
\hline
\end{tabular}


Table 3 (continued)

\begin{tabular}{|c|c|c|c|c|c|}
\hline \multirow{3}{*}{$\begin{array}{c}\text { Sample } \\
\text { no. }\end{array}$} & \multirow{3}{*}{$\begin{array}{c}\text { Total } \\
\text { dilution } \\
\text { factor }\end{array}$} & \multicolumn{3}{|c|}{ Sperm count $\times 10^{6} / \mathrm{ml}$} & \multirow{3}{*}{$\begin{array}{c}T \text { value } \\
\text { from the } \\
\text { size dis- } \\
\text { tribution } \\
\text { curve } \\
M_{\ddagger} \text { Mean } \\
T_{\ddagger}\end{array}$} \\
\hline & & \multirow[b]{2}{*}{ Manual } & \multicolumn{2}{|c|}{ Coulter } & \\
\hline & & & $\begin{array}{c}\text { Cor- } \\
\text { rected }\end{array}$ & $\begin{array}{l}\text { Uncor- } \\
\text { rected* }\end{array}$ & \\
\hline \multicolumn{6}{|c|}{ Oligospermia, Grade II, without peak } \\
\hline $\begin{array}{l}51 \\
63 \\
44 \\
56 \\
76 \\
78 \\
62\end{array}$ & $\begin{array}{l}2000 \\
2000 \\
1000 \\
2000 \\
2000 \\
1000 \\
1000\end{array}$ & $\begin{array}{r}35 \\
27 \\
32 \\
15 \\
23 \\
5\end{array}$ & $\begin{array}{l}23 \cdot 4 \\
29 \cdot 6 \\
25 \cdot 1 \\
23 \cdot 0 \\
19 \cdot 4 \\
18 \cdot 2 \\
16 \cdot 4\end{array}$ & $\begin{array}{l}35 \cdot 8 \\
47 \cdot 6 \\
30.9 \\
57 \cdot 0 \\
26 \cdot 6 \\
36 \cdot 6 \\
21 \cdot 3\end{array}$ & $\begin{array}{l}57.5 \\
57.0 \\
44.5 \\
95.0 \\
50.0 \\
54.0 \\
43.0\end{array}$ \\
\hline \multicolumn{6}{|c|}{ Oligospermia, Grade III, without peak } \\
\hline $\begin{array}{l}24 \\
30 \\
64 \\
28 \\
66 \\
29 \\
70 \\
55 \\
23 \\
69 \\
45\end{array}$ & $\begin{array}{r}250 \\
250 \\
2000 \\
400 \\
1000 \\
250 \\
1000 \\
1000 \\
286 \\
1000 \\
100\end{array}$ & $\begin{array}{r}16 \\
9 \\
7 \\
5 \\
4 \\
13 \\
13 \\
11 \\
7 \\
5 \\
5\end{array}$ & $\begin{array}{r}11 \cdot 0 \\
8.2 \\
10 \cdot 6 \\
10.1 \\
5.2 \\
10.1 \\
8.2 \\
8.0 \\
6.5 \\
5.5 \\
4.8 \\
\end{array}$ & $\begin{array}{r}20 \cdot 1 \\
16 \cdot 5 \\
19 \cdot 0 \\
10 \cdot 5 \\
7 \cdot 4 \\
18 \cdot 3 \\
12 \cdot 3 \\
12 \cdot 1 \\
8 \cdot 0 \\
9 \cdot 1 \\
7 \cdot 3 \\
\end{array}$ & $\begin{array}{l}63 \cdot 5 \\
70 \cdot 5 \\
60 \cdot 0 \\
48 \cdot 0 \\
45 \cdot 0 \\
64 \cdot 0 \\
47 \cdot 5 \\
51.0 \\
43 \cdot 5 \\
52 \cdot 5 \\
56 \cdot 0\end{array}$ \\
\hline \multicolumn{6}{|l|}{ Azoospermia } \\
\hline $\begin{array}{l}27 \\
21 \\
47 \\
48 \\
58 \\
68 \\
73 \\
75 \\
79\end{array}$ & $\begin{array}{r}1333 \\
250 \\
2000 \\
2000 \\
1000 \\
2000 \\
2000 \\
2000 \\
1000\end{array}$ & $\begin{array}{l}0 \ddagger \\
0 \\
0 \\
0 \\
0 \\
0 \\
0 \\
0 \\
0\end{array}$ & $\begin{array}{r}6.0 \\
3.2 \\
10 \cdot 1 \\
5 \cdot 0 \\
1 \cdot 1 \\
3 \cdot 1 \\
5 \cdot 1 \\
16.9\end{array}$ & $\begin{array}{r}7.0 \\
3.0 \\
9.4 \\
11.2 \\
21.2\end{array}$ & \\
\hline
\end{tabular}

Paired figures represent samples from the same patient.

* See text.

$\dagger$ Very reduced tails.

$\ddagger$ Some sperm remnants found.

and those without peaks. In most cases, the peak appeared to be in approximately the same position as were those from the normospermic patients except for that of Patient no. 34 where it was markedly to the left since the spermatozoa were small in size. In general, the peaks were smaller and less sharp than in the 'normal' series and some peaks were only just detectable. There was a gradual progression to the smooth curves. Table 4 shows that a peak was always found when the count was greater than $30 \times 10^{6}$ spermatozoa $/ \mathrm{ml}$. Above $12 \times 10^{6}$ spermatozoa $/ \mathrm{ml}$, only seven out of a total of twenty-five patients did not show a peak. Below $12 \times 10^{6}$ spermatozoa $/ \mathrm{ml}$, none of the curves showed a peak. It was not possible to obtain a valid count for specimens containing less than $5 \times 10^{6} / \mathrm{ml}$ by the Coulter counter or the haemocytometer 


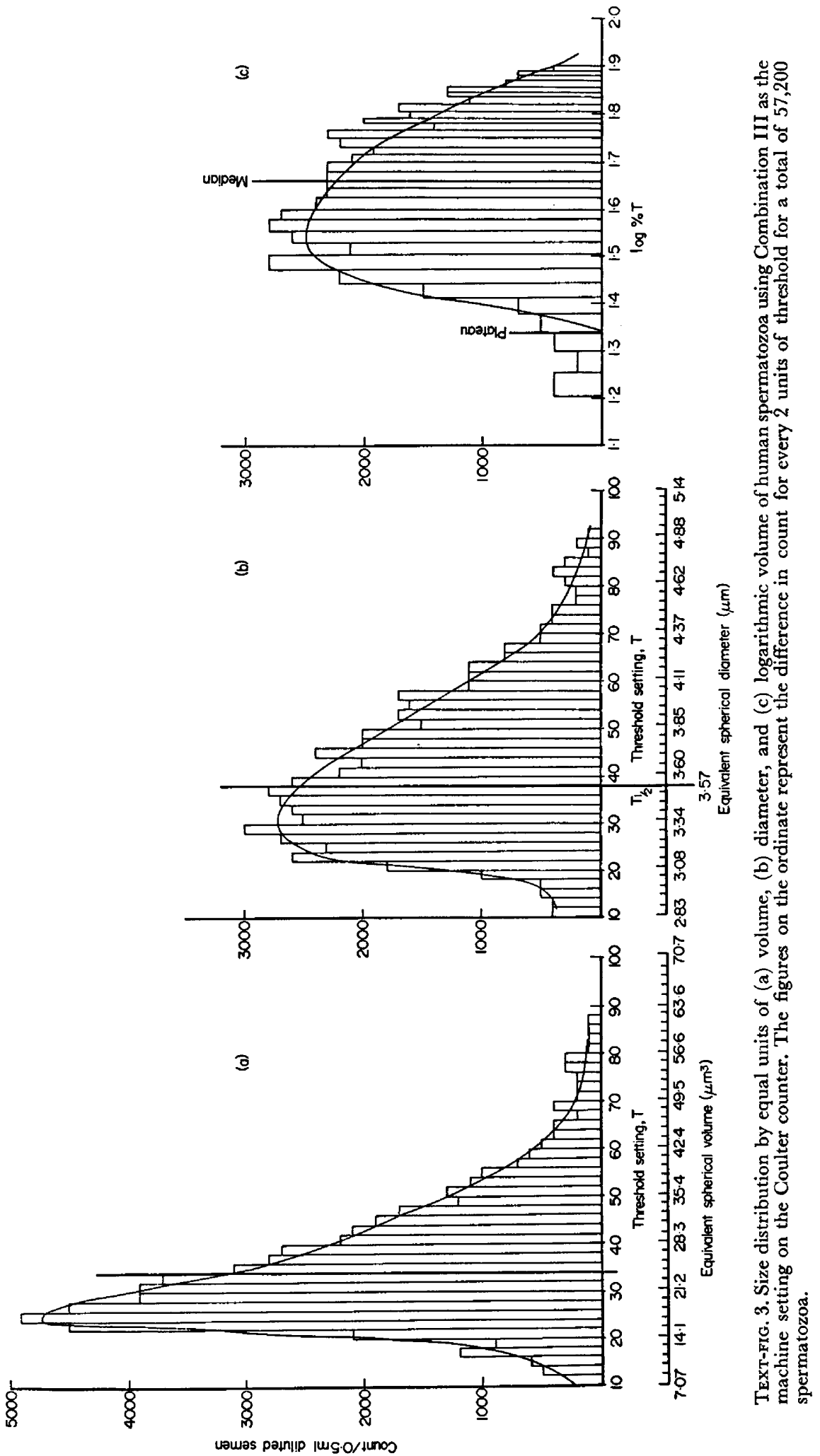


method. The difference between the 'corrected' and 'uncorrected' Coulter counts was much greater than for those in the 'normal' series. This reflected the greater quantities of larger débris present in the oligospermic series, mostly

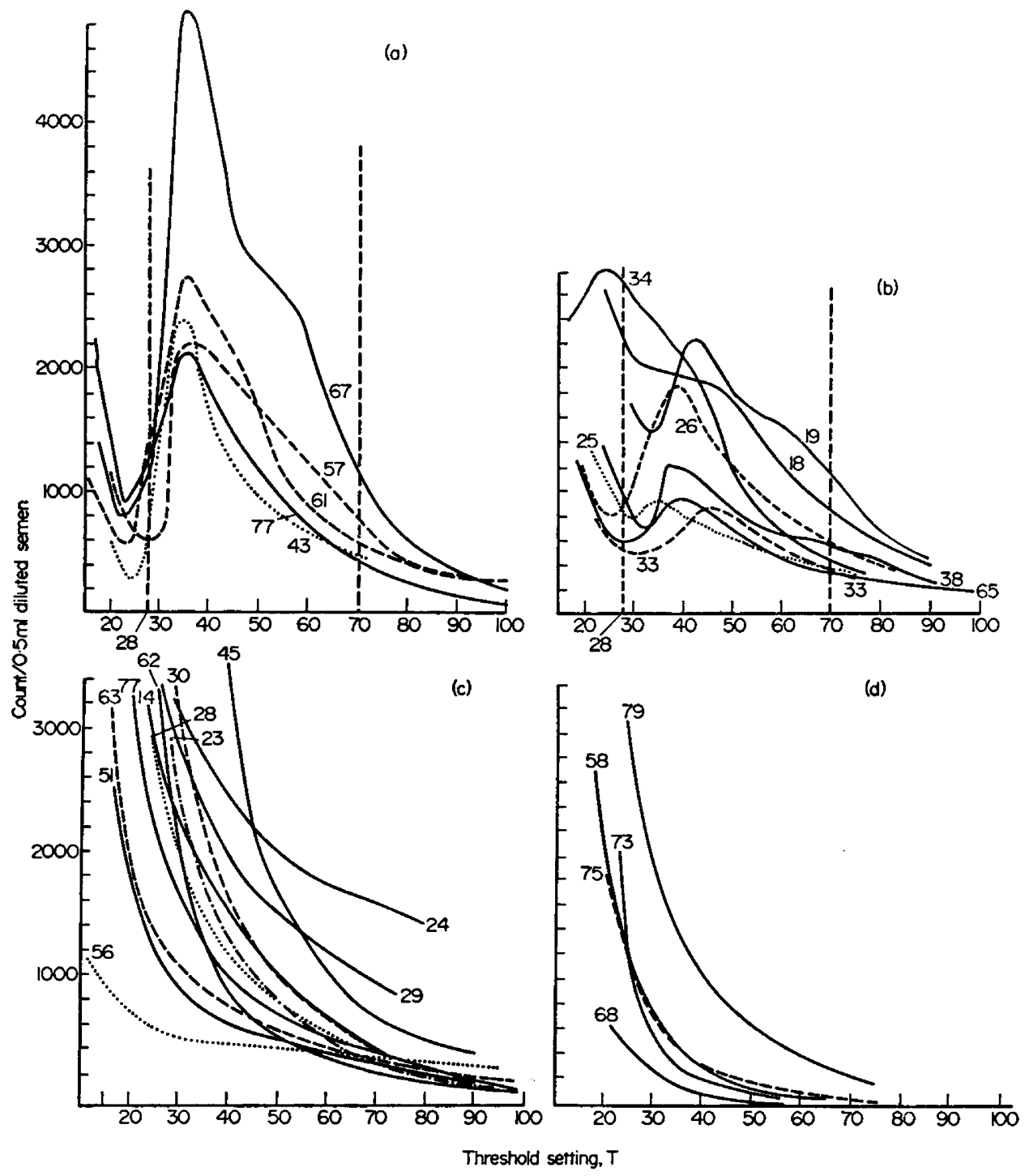

Text-Frg. 4. Size distribution curves of human spermatozoa in (a) normospermic semen samples; (b) oligospermic semen samples that showed a peak; (c) oligospermic semen samples that did not show a peak; (d) azoospermic semen samples. Combination II of the machine setting on the Coulter counter was used. The figures along the ordinate represent the difference in count for each 2 units of threshold. The total count of spermatozoa in (a) and (b) was made between $T=28$ and $T=70$.

represented by 'cells'. When this débris was included in the 'uncorrected' count and multiplied by the total dilution factor, a large error was introduced. This was removed by using an upper T level as described in the 'Methods'. 
The sperm counts of the four patients who were seen twice fell within the same general range on both occasions.

There were nine patients with azoospermia as judged by the original semen examination. Their semen particle size distributions are shown in Text-fig. 4d for Combination II and their data are summarized in Table 4. More detailed microscopic examination later revealed that there were a few sperm fragments present in the specimen from Patient no. 27. All the specimens behaved in the Coulter counter as if they had a finite sperm count and this varied from $1 \cdot 1$ to $16.9 \times 10^{6}$ 'spermatozoa' $/ \mathrm{ml}$ semen.

The data from all sixty-eight patients for which a particle size distribution and 'corrected' count were obtained are summarized in Table 4 using the sperm classification system of Conrads (1971). There was general agreement

Table 4. Summary of specimens classified according to grade of oligospermia

\begin{tabular}{|c|c|c|c|c|c|}
\hline $\begin{array}{l}\text { Type of } \\
\text { sample }\end{array}$ & $\begin{array}{l}\text { Sperm count } \\
\text { (millions } / \text { ml })\end{array}$ & $\begin{array}{l}\text { No. of } \\
\text { samples }\end{array}$ & $\begin{array}{c}\text { No. of } \\
\text { patients } \\
\text { seen twice }\end{array}$ & $\begin{array}{c}\text { No. of } \\
\text { samples } \\
\text { without a } \\
\text { peak in the } \\
\text { size } \\
\text { distribution }\end{array}$ & $\begin{array}{l}\text { No. of results } \\
\text { for which } \\
\text { manual and } \\
\text { Coulter counts } \\
\text { were compared }\end{array}$ \\
\hline $\begin{array}{l}\text { Polyspermia } \\
\text { Normospermia }\end{array}$ & $\begin{array}{c}>250 \\
40 \text { to } 249\end{array}$ & $\begin{array}{r}1 \\
24\end{array}$ & - & $\begin{array}{l}0 \\
0\end{array}$ & $\begin{array}{r}0 \\
11\end{array}$ \\
\hline $\begin{array}{c}\text { Oligospermia } \\
\text { Grade I } \\
\text { Grade II } \\
\text { Grade III }\end{array}$ & $\begin{array}{c}30 \text { to } 39 \\
12 \text { to } 29 \\
<12\end{array}$ & $\begin{array}{r}3 \\
22 \\
9\end{array}$ & $\begin{array}{r}\overline{2} \\
2\end{array}$ & $\begin{array}{l}0 \\
7 \\
9\end{array}$ & $\begin{array}{l}3 \\
21 \\
11\end{array}$ \\
\hline Azoospermia & Nil & $9 *$ & - & - & - \\
\hline Total & & 68 & 4 & 16 & 46 \\
\hline
\end{tabular}

* In semen specimens from one patient, some sperm remnants were found at higher magnification.

with this classification of the particle size distribution curves in that normospermia was more properly regarded as $>40 \times 10^{6}$ spermatozoa $/ \mathrm{ml}$ rather than $>20 \times 10^{6}$ spermatozoa $/ \mathrm{ml}$ and that three grades of oligospermia were discernible. Above $30 \times 10^{6}$ spermatozoa/ml (Grade I), the curves always showed a peak whereas Grade II showed a mixed group. It is considered that the dividing line between Grade II and Grade III oligospermia should be $12 \times 10^{6} /$ $\mathrm{ml}$ rather than $10 \times 10^{6} / \mathrm{ml}$ as a peak was consistently absent below this level.

\section{EXPLANATION OF PLATE 1}

FIg. 1. A semen sample from Patient no. $74\left(114 \times 10^{6}\right.$ spermatozoa $\left./ \mathrm{ml}\right)$. No normal spermatozoa were seen. $\times 650$.

Fig. 2. A semen sample from Patient no. $37\left(95.2 \times 10^{6}\right.$ spermatozoa $\left./ \mathrm{ml}\right)$ showing vacuoles in the sperm heads. $\times 1575$.

Frg. 3. A semen sample from Patient no. $54\left(24.6 \times 10^{6}\right.$ spermatozoa/ml $)$ showing several different sperm tail abnormalities. $\times 1575$.

Fig. 4. A semen sample from Patient no. $63\left(29.6 \times 10^{6}\right.$ spermatozoa/ml $)$ showing abnormal sperm heads. $\times 1575$. 
PIATI: 1
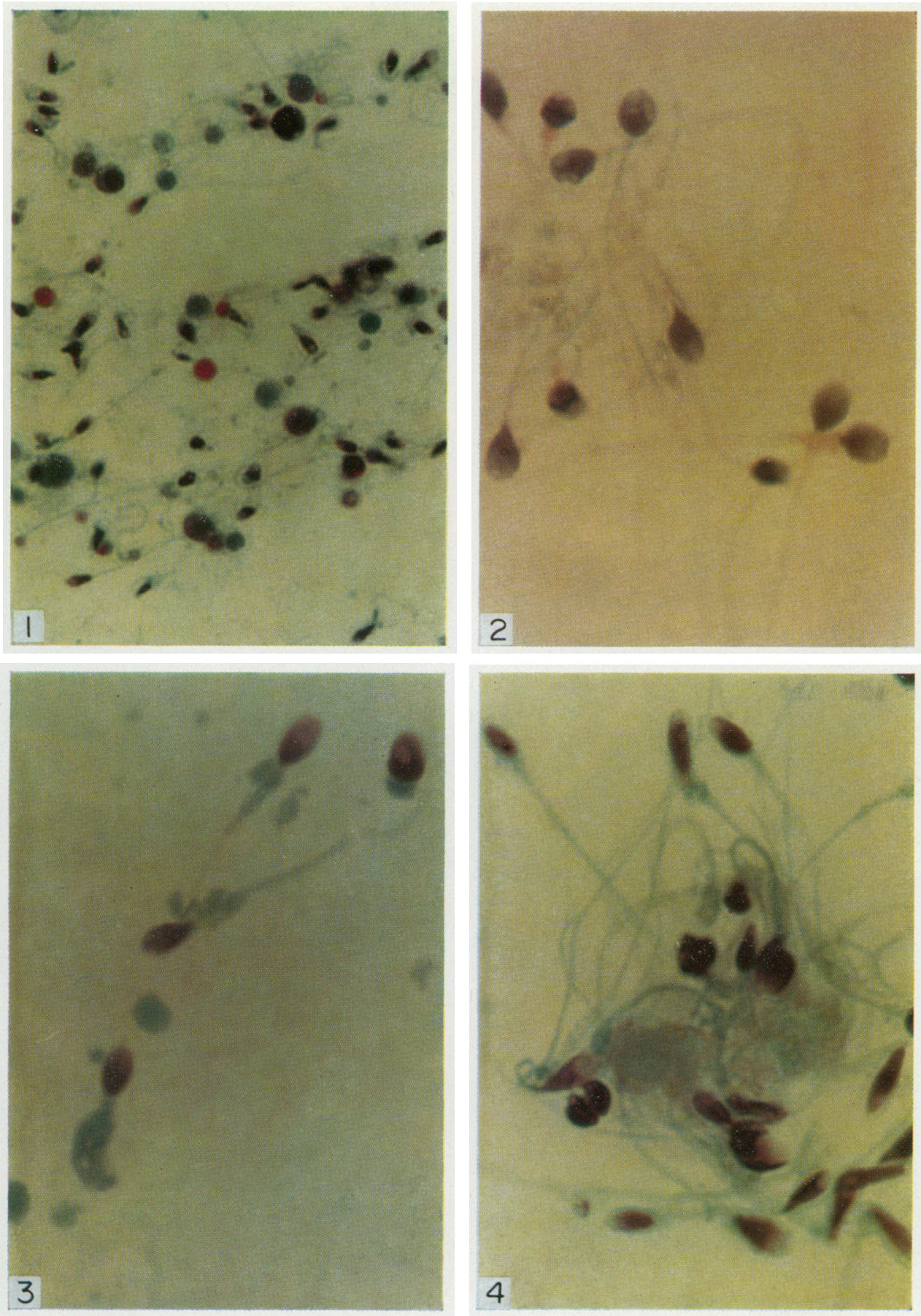

(Facing 1.352 
Sperm size

The characteristics of the curves in the three categories have been summarized in Table 4. There was a distinct but non-significant tendency for the $T_{\frac{1}{2}}$, minima and maxima (peak) for the oligospermic men to be greater than those of the 'normals', since the spermatozoa in the oligospermia semen samples were larger. This is shown more clearly when the individual values in Table 4 are examined when it is seen that several of the samples were extremely abnormal.

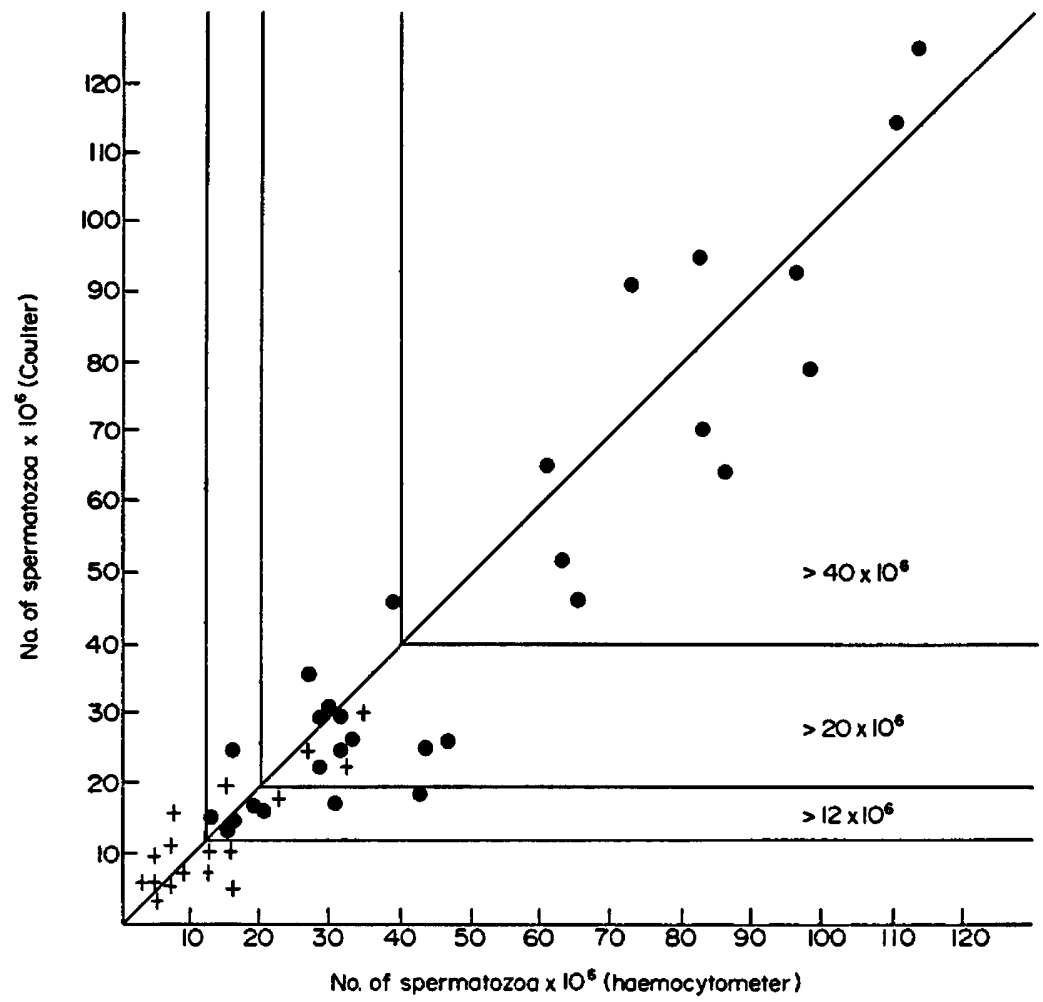

TEXT-FIG. 5. The correlation between Coulter counter (ordinate) and haemocytometer counts (abscissa) of human spermatozoa. @, Samples which showed a peak, +, samples which did not show a peak.

It was decided that Combination II was the most useful for the determination of sperm size distribution and sperm dimensions. The maximum (mode) for the twenty-five 'normal' specimens occurred at a mean of $\mathrm{T}=38.8$ which is equivalent to $\mathrm{V}=19.4 \pm 1.5 \mu \mathrm{m}^{3}$ (S.D.) or $\mathrm{d}=3.33 \mu \mathrm{m}$. The $\mathrm{T}_{\frac{1}{2}}$ value (mean) for the twenty-five 'normal' specimens occurred at a mean of $\mathrm{T}=51.2$ which is equivalent to $\mathrm{V}=25.6 \pm 2.6 \mu \mathrm{m}^{3}$ (S.D.) or $\mathrm{d}=3.65 \mu \mathrm{m}$. These values may be taken as defining the size of human spermatozoa when they are considered in terms of an equivalent sphere.

\section{Correlation with manual counts}

Text-figure 5 shows a plot of the corrected Coulter count against the haemo- 
cytometer count. Excluding the azoospermic specimens, the correlation coefficient was 0.993 and the calculated line did not differ from the theoretical line as drawn. Most of the distribution about the line is believed to be due to errors in the haemocytometer count.

\section{Microscopical examination}

A few of the semen specimens were heavily infected with motile bacteria and this was usually associated with the presence of a high proportion of abnormal spermatozoa. These infections had not produced sufficient symptoms for clinical detection.

Generally, it was extremely difficult to decide if any of the specimens could be regarded as completely normal, even the twenty-five specimens placed in the 'normal' category on the basis of their sperm count. The single 'hyperspermic' specimen (Patient no. 32) was considered to be as normal as any of the other specimens although the count was $476 \times 10^{6}$ spermatozoa $/ \mathrm{ml}$. Of the five specimens with counts greater than $100 \times 10^{6}$ spermatozoa $/ \mathrm{ml}$, one (Patient no. 74) was so abnormal that no normal spermatozoa could be found among the mass of cells and sperm fragments (Pl. 1, Fig. 1). Abnormalities of this type were best detected by examination of stained slides.

Some specimens with a high, that is 'normal', sperm count also exhibited abnormal sperm structure. For example, samples from Patient no. 37 $\left(95.2 \times 10^{6}\right.$ spermatozoa $\left./ \mathrm{ml}\right)$ showed a high proportion of vacuoles in the sperm heads (Pl. 1, Fig. 2), and those from Patient no. 61 (79.2 $\times 10^{6}$ spermatozoa $/ \mathrm{ml}$ ) showed a high proportion of abnormal spermatozoa.

The division between 'normospermia' and oligospermia made at $40 \times 10^{6}$ spermatozoa/ml was extremely arbitrary as there was no clear-cut division at this point in terms of sperm structure. As the sperm count in the series gradually decreased, however, the proportion of abnormal forms gradually increased. Abnormalities in the sperm tail were very common, varying from 'fuzzy' tails to short tails, to a blob of cytoplasm instead of tails (Patient no. 54, Pl. 1, Fig. 3), to no tails at all (Patient no. 45). The spermatozoa from Patient no. 34 were noted as having very reduced tails and this showed on the size distribution where the peak was far removed to the left. Some patients produced a mass of cells (nos. 25 and 64). There were many cases of abnormalities in the sperm head, including split heads, and double heads (Patient no. 63, Pl. 1, Fig. 4). Some men produced blue-staining round nuclei (which might be pyknotic sperm heads) in a mass of blue cytoplasm and débris (Patients nos. 69 and 62). In most cases, it was not possible to identify these abnormal forms with any of the standard stages in the production of human spermatozoa as illustrated by de Kretser (1969). In other words, the forms produced were abnormal and not merely juvenile or undeveloped stages of normal spermatogenesis.

\section{DISGUSSION}

The size of human spermatozoa has been elaborately measured under the light microscope (van Duijn, 1958). Equations were deduced for calculating the volume of the different parts of a spermatozoon and the volume total was 
estimated as between 13.0 and $17.3 \mu \mathrm{m}^{3}$. These values are slightly smaller than the mean volumes of Zaponin-treated spermatozoa reported here as between 17.8 and 23.3 (mean 19.3) $\mu \mathrm{m}^{3}$ but are in the same range. These results also agree with those of Gordon et al. (1965) who, using a Coulter counter model $\mathrm{B}$, reported a range of 10 to $22 \mu \mathrm{m}^{3}$ with a mode of $15 \mu \mathrm{m}^{3}$, but not with those of Segal \& Laurence (1962) who gave a range of 28.0 to $78.4 \mu \mathrm{m}^{3}$ with a mean of $56.0 \mu \mathrm{m}^{3}$. These latter results are probably due to inadequate calibration of the Coulter counter as only one standard particle was used. This procedure has been shown to be capable of producing large errors (Brotherton, 1969a, b, 1971).

The loss in sperm volume due to the Zaponin treatment is believed to be negligible both from comparison with the microscopical measurements of van Duijn (1958) and from comparison with the effect of the cetrimidecitrate-saline reagent. The latter is a more powerful reagent which has been shown to remove more cytoplasm from leucocytes than the Zaponin reagent, thus producing smaller remnants of more uniform size for counting (Brotherton, 1969a). The fact that this reagent had virtually the same effect as Zaponin on human spermatozoa indicated the smallness and insignificance of the cytoplasmic envelope removed. That the tails were not removed was an important effect from the point of view of measuring the total sperm size. The thinness of the cytoplasm of human spermatozoa has been demonstrated by electron microscopy (Bedford, 1967; Pedersen, 1969; Zamboni, Zemjanis \& Stefanini, 1971).

The possibility must be considered that the positive skewness of the size distribution of human spermatozoa may be due to the presence of X- and Ybearing spermatozoa with slightly different sizes. Theoretically, the X-bearing spermatozoa are slightly larger than the Y-bearing spermatozoa. The Y-bearing spermatozoa can be identified by the fluorescence of the $\mathrm{Y}$ chromosome (Pearson, 1972) and the proportion of Y-bearing spermatozoa has now been established as $50 \%$ within experimental error for normal samples (Pawlowitzki \& Pearson, 1972). A consideration of the theoretical size difference between the two types of spermatozoa shows that the X-bearing spermatozoa should be larger, the $\mathrm{X}$ chromosome contributing $1 / 23$ of the total mass of DNA assuming the $\mathrm{X}$ chromosome to be of medium size. The sperm head only accounts for about $42 \%$ of the total sperm volume (van Duijn, 1958), some of which consists of surrounding cytoplasm, cell wall and the basic proteins associated with the DNA. The extra volume associated with an X chromosome would appear to be insignificant. It is now accepted that the two types of spermatozoa cannot be distinguished by observation of their size and shape (Rothschild, 1960; van Duijn, 1961).

Using fluorescence techniques and DNA measurements, it has been demonstrated that human semen contains 1 to $5 \%$ of fully diploid spermatozoa (Sumner, 1971; Sumner, Robinson \& Evans, 1971; Pawlowitzki \& Pearson, 1972). Assuming one tail in this situation, there should be an increase in size of the sperm head, the maximum possible increase being twice the normal volume, which would increase the total sperm volume from about $19 \mu \mathrm{m}^{3}$ to about $27 \mu \mathrm{m}^{3}$. This increase does not account for the skewness of the size 
distribution curve which extends up to $60 \mu \mathrm{m}^{3}$ with a mean of about $24 \mu \mathrm{m}^{3}$. There seems, therefore, to be no explanation for the skewness of the size distribution curves other than that this is an inherent property of the cells.

The types of cells and abnormal sperm forms occurring in ejaculates have been described and illustrated by diagrams (Documenta Geigy, 1960; MacLeod, 1965; Joël, 1971). Attempts have been made (Joël, 1971) to relate these forms to the normal process of spermatogenesis in man, which has been described by Pedersen (1969) using the electron microscope and by Clermont (1972) using the light microscope, with the assumption that all the types of cells involved in spermatogenesis may sometimes be ejaculated. A variety of terms have been used to describe some of the more common types of abnormalities, for example asthenospermia (poor motility), teratospermia (more than $40 \%$ abnormal forms), necrospermia (spermatozoa showing necrosis or pyknosis-Schirren, 1972), pyospermia (a mass of undefined cells) and spermatophagia (spermatozoa being digested by leucocytes-Joël, 1971). These terms have often been used as alternatives to describing the degree of oligospermia when grading a specimen in terms of possible fertility. The use of some of these special terms does not seem to be realistic, for example a count of $110 \times 10^{6}$ spermatozoa $/ \mathrm{ml}$ but the production of totally abnormal forms does not fit in with any of the classifications. It is considered that the degree of oligospermia should be stated as a separate parameter and the other terms should be used to describe the microscopic picture. For a full assessment of oligospermia, a microscopic examination is still believed to be essential. The finite counts obtained with the Coulter counter in cases of azoospermia are believed to reflect the miscellaneous cell débris present in these specimens. It was concluded that the Coulter counter was not suitable for semen specimens containing less than $5 \times 10^{6}$ spermatozoa $/ \mathrm{ml}$. Any count below $20 \times 10^{6}$ spermatozoa $/ \mathrm{ml}$ should be viewed with suspicion unless it is validated by a haemocytometer count. Once spermatozoa have been shown to be present, certain arbitrary classifications are possible based on the total count using the Coulter counter.

\section{ACKNOWLEDGMENTS}

We wish to thank most warmly Dr D. B. Carruthers for access to patients attending his subfertility clinic at the Family Planning Association. We are also indebted to Mr P. Evans of the Seminology Department of the Middlesex Hospital for the haemocytometer counts and to Mr J. R. Newton, F.R.c.o.G., of King's College Hospital Medical School, for access to some of the early cases.

\section{REFERENGES}

BEDFord, J. M. (1967) Observations on the fine structure of spermatozoa of the bush baby, the African green monkey and man. Am. F. Anat. 121, 443.

Brotherton, J. (1969a) Galibration of a Goulter Counter Model F for size determination of cells. Cytobios, $1,95$.

Brotherton, J. (1969b) Calibration of the Coulter Counter Medical Model B for cell size determination. Cytobios, 1, 307. 
Brotherton, J. (1971) Calibration of the Goulter Gounter model A for the size determination of cells. Proc. Soc. analyt. Chem. 8, 264.

Clermont, Y. (1972) Kinetics of spermatogenesis in mammals: seminiferous epithelium cycle and spermatogonal renewal. Physiol. Rev. 52, 198.

Conrads, R. (1971) Diagnostik bei Infertitlität des Mannes und Hypogonadismus. Therapiewoche, 211,3941 .

D'Angelo, G. \& Lacombe, M. (1962) A practical diluent for electronic white cell counts. Am. $\mathcal{J}$. clin. Path. 38, 658.

DE KRETSER, D. M. (1969) Ultrastructural features of human spermiogenesis. Z. Zellforsch. mikrosk. anat. $98,477$.

Documenta Geigy (1960) 6th Edn., pp. 568-573. J. R. Geigy A.G., Basel.

Eliasson, R. (1971) Standards for investigation of human semen. Andrologie, 3, 49.

Fowler, A. K. \& Hellman, G. (1965) An electronic method for counting and sizing rabbit spermatozoa. Fert. Steril. 16, 778.

Glover, F. A. \& Phipps, L. W. (1962) Preliminary study of an electronic method of counting and sizing bull spermatozoa. 7. Reprod. Fert. 4, 189.

Gordon, D. L., Moore, D. J., Thorslund, T. \& Paulsen, G. A. (1965) The determination of size and concentration of human sperm with an electronic particle counter. 7. Lab. clin. Med. 65, 506.

Iversen, S. (1964) Evaluation of the number of spermatozoa in bull semen. A comparison between electronic counting, light scattering and absorbtiometry. 7. agric. Sci., Camb. 62, 219.

Jö̈L, C. A. (1971) Fertility Disturbances in Men and Women, p. 85. Karger, Basel.

Kilhström, J. E. \& Fjel.Lström, D. (1967) Automatic counting of spermatozoa in rabbit semen. 7. Reprod. Fert. 14, 155.

Laurence, K. A. \& Garpuk, O. (1963) The counting and sizing of guinea pig spermatozoa. Fert. Steril. 14, 451.

MacLeod, J. (1965) The semen examination. Clin. Obstet. Gynec. 8, 115.

Pawlowitzki, I. H. \& Pearson, P. L. (1972) Chromosomal aneuploidy in human spermatozoa. Humangenetik, 16, 119.

Pearson, P. (1972) The use of new staining techniques for human chromosome identification. Jnl med. Genet. 9, 264.

Pedersen, H. (1969) Ultrastructure of ejaculated human sperm. Z. Zellforsch. mikrosk. anat. 94, 542.

Rothschild, LoRd (1960) X and Y spermatozoa. Nature, Lond. 187, 253.

Schirren, C. (1972) Practical Andrology. Verlag Brüder Hartman, Berlin.

Segal, S. J. \& Laurence, K. A. (1962) Automatic analysis of particulate matter in human semen. Ann. N.Y. Acad. Sci. 99, 271.

Stranzinger, G. \& Paufler, S. (1968) Vergleichende Untersuchungen über Spermadichtmessungen mit der Thoma-Kammer Neu, dem Eppendorf-Photometer und dem Coulter-Counter model B bei Bullenejakulaten. Zuchthygiene, 3, 191.

Stranzinger, G. \& Paufler, S. (1969) Vergleichende Untersuchungen über Spermadichtmessungen beim Kanichen mit dem elektronischen Partikelzählgerat Coulter-Counter Model B und der Zählkammer. Zuchthygiene, 4, 121.

Sumner, A. T. (1971) Frequency of polyploid spermatozoa in man. Nature, Lond. $231,49$.

Sumner, A. T., Robinson, J. A. \& Evans, H. J. (1971) Distinguishing between X, Y and XY-bearing human spermatozoa by fluorescence and DNA content. Nature, New Biology, 229, 231.

VAN Duijn, C. (1958) Biometry of human spermatozoa. Fl $R$. microsc. Soc. 77, 12.

van DujJ, G. (1961) Size frequency distributions in spermatozoa. Fert. Steril. 12, 509.

Zamboni, L., Zemjanis, R. \& Stefanini, M. (1971) The fine structure of monkey and human spermatozoa. Anat. Rec. 169, 129. 